\title{
Treatment of human hepatocellular carcinoma by the oncolytic herpes simplex virus G47delta
}

\author{
Jiani Wang ${ }^{1 \dagger}$, Lihua $\mathrm{Xu}^{2+}$, Weigen Zeng ${ }^{1,3}$, Pan Hu${ }^{1}$, Musheng Zeng ${ }^{4}$, Samuel D Rabkin ${ }^{5}$ and Renbin Liu ${ }^{* *}$
}

\begin{abstract}
Background: Oncolytic herpes simplex virus (HSV) can replicate in and kill cancer cells while sparing the adjacent normal tissue. Hepatocellular carcinoma (HCC) is amongst the most common and lethal cancers, especially in Third World countries. In this study, the cytotoxicity of a third-generation oncolytic HSV, G47 human HCC cell lines and in an immortalized human hepatic cell line. Additionally, subcutaneous models of HCC were established to evaluate the in vivo anti-tumor efficacy of G47 $\Delta$.

Methods: The HepG2, HepB, SMMC-7721, BEL-7404, and BEL-7405 human HCC cell lines and the HL-7702 human hepatic immortalized cell lines were infected with G47 $\Delta$ at different multiplicities of infection (MOls). The viability of infected cells was determined, and the G47 $\Delta$ replication was identified by X-gal staining for LacZ expression. Two subcutaneous (s.c.) HCC tumor models of HCC were also established in Balb/c nude mice, which were intratumorally (i.t.) treated with either G47 $\Delta$ or mock virus. Tumor volume and mouse survival times were documented.
\end{abstract}

Results: More than 95\% of the HepG2, Hep3B,and SMMC-7721 HCC cells were killed on by day 5 after infection with a MOl's of 0.01 . For the HL-7702 human hepatic immortalized cells, $100 \%$ of the cells were killed on by day 5 after infection with a MOl's of 0.01 . The BEL-7404 HCC cell line was less susceptible with about $70 \%$ cells were killed by day 5 after infection with a MOl's of 0.01 . Whereas the BEL-7405 HCC cells were the least susceptible, with only $30 \%$ of the cells were killed. Both the SMMC-7721 and BEL-7404 cells form aggressive sc tumor models. G47 $\Delta$ replicates in the tumors, such that most of the tumors regressed after the G47 $\Delta$-treatment, and treated tumor-bearing mice survived much longer than the control animals.

Conclusions: G47 $\Delta$ effectively kills human HCC cells and an immortalized hepatic cell line at low MOl. Intra-tumor injection of G47 $\Delta$ can induce a therapeutic effect and prolong the survival of treated mice bearing SMMC-7721 and BEL-7404 subcutaneously (s.c.) tumors. Thus, G47 $\Delta$ may be useful as a novel therapeutic agent for HCC.

Keywords: Hepatocellular carcinoma, Oncolytic herpes simplex virus, Cytotoxicity, Subcutaneous model

\section{Introduction}

Hepatocellular carcinoma (HCC) is one of the most common and lethal malignancies worldwide [1-3]. It is more frequent among men than women, and the morbidity increases gradually with age. More than one million worldwide cases of HCC occur each year [4]. The incidence is highest in Third World countries, and a rising incidence has been recently been observed in developed countries.

\footnotetext{
*Correspondence: liur@vip.163.com

${ }^{\dagger}$ Equal contributors

'Breast Cancer Center, The Third Affiliated Hospital of Sun Yat-sen University, 600 Tianhe Road, 510630 Guangzhou, China

Full list of author information is available at the end of the article
}

The major etiological factors associated with $\mathrm{HCC}$ are infection with the hepatitis B (HBV) or C (HCV) viruses, chronic inflammatory liver lesions, necrosis of hepatocytes and subsequent fibrosis, long term exposure to high levels of AFBI or vinyl chloride in the diet, and heavy alcohol consumption [5]. At least one of these etiological factors can be identified, either alone or in combination with another factor [6-8]. Both HBV and $\mathrm{HCV}$ cause acute and chronic infections that are associated with over $80 \%$ of $\mathrm{HCC}$ cases worldwide, with most infected individuals remaining asymptomatic for many years $[9,10]$. It is estimated that approximately $10 \%$ to $40 \%$ of chronic HBV carriers eventually suffer from liver cancer $[9,11]$.

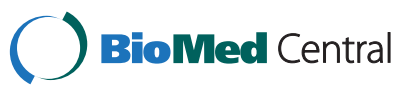

(c) 2014 Wang et al.; licensee BioMed Central Ltd. This is an Open Access article distributed under the terms of the Creative Commons Attribution License (http://creativecommons.org/licenses/by/2.0), which permits unrestricted use, distribution, and reproduction in any medium, provided the original work is properly credited. The Creative Commons Public Domain Dedication waiver (http://creativecommons.org/publicdomain/zero/1.0/) applies to the data made available in this article, unless otherwise stated. 
Currently, several treatment modalities are considered to have curative potential: hepatic resection, liver transplantation, percutaneous radiofrequency ablation, and transarterial chemoembolization [12,13]. Recent progress in these treatment approaches has contributed to the improved survival rate of HCC patients [13]. Improvements in surgical techniques have led to significant advances in liver surgery, which have led to a substantial reduction in HCC mortality. The parallel development of laparoscopic surgery has also provided several advantages [14], although it is not routinely used [15].

However, there are limitations on these therapeutic options. HCC treatment depends on the stage of the tumor, the clinical characteristics, and the degree of liver dysfunction [16]. Patients must be diagnosed at an early stage and fulfill certain criteria. Unfortunately, HCC patients remain asymptomatic, and the majority of patients are not diagnosed until the tumor is in an advanced, non-resectable stage. Systemic chemotherapy is also disappointing, with low response rates and high toxicity. Treatment possibilities for these patients are limited. Hence, a new strategy that targets HCC specifically and effectively is needed.

One of the major goals of antitumor therapies is to target tumor cells selectively and specifically, while sparing adjacent healthy tissue from destruction. Oncolytic herpes viruses have been proposed as useful anti-tumor agents that kill dividing tumor cells but not normal tissue [17]. These viruses may be a new treatment strategy for malignant hepatic tumors.

Oncolytic herpes simplex viruses (HSVs) provide a potential therapeutic strategy that targets malignant tumors without damaging adjacent normal tissue. Replication of a single HSV can kill the host cell and release new virions, which can infect adjacent cells. Because these viruses destroy tumor cells by oncolysis, they have no cross-resistance with other therapy strategies, such as radiotherapy and chemotherapy; thus, they can serve as a complement to these therapeutic approaches.

Since oncolytic HSV was first described to treat brain tumors in 1991 [18], the unique biological characteristics of HSV have been improved by the development of additional HSV vectors that confer safety and specificity [19]. Over 20 different oncolytic HSV vectors have been evaluated in a large variety of different tumor types [19], including human pancreatic, gastric, and prostate cancer and mouse bladder and colorectal cancer [20-26]. Currently, six oncolytic HSV vectors, G207, G47 , 1716, HF10, NV1020, and Oncovex ${ }^{\text {GM-CSF }}$ (talimogene laherparepvec) have progressed to clinical trials, with Oncovex ${ }^{\text {GM-CSF }}$ successfully reaching its primary endpoint in a randomized phase III trial for metastatic melanoma [19,27-29].

The virus investigated in this study is a third generation oncolytic HSV, G47 $\Delta$. It contains three principle mutations that result in its selective cytotoxicity to tumor cells. The $\gamma 34.5$ gene precludes the shut-off of protein synthesis in host cells [19], and the $\gamma 34.5$-deletion limits virus replication to cells lacking innate immune responses. The UL39 gene encodes for ICP6, the large subunit of viral ribonucleotide reductase, which is a key enzyme for deoxyribonucleic acid synthesis in nondividing cells [19]. A lacZ gene insertion in the UL39 gene inactivates it and blocks virus DNA replication in normal cells [21]. Deletion of the ICP47 gene places the US11 gene under the control of the immediate-early $\alpha 47$ promoter, which results in the amplification of $\gamma 34.5$ - mutant growth. Furthermore, the ICP47- mutation increases MHC class I presentation, which stimulates lymphocytes and decreases Natural Killer (NK) cytolysis of host cells [30]. These important features enhance the antitumor immune responses following treatment with G47 $\Delta$.

In this study, we investigated the cytotoxic effects of G47 $\Delta$ on five human HCC cell lines and one immortalized human hepatic cell line. Furthermore, we evaluated the therapeutic effects of G47 $\Delta$ in s.c. xenograft models of two human HCC cell lines.

\section{Materials and methods}

\section{Ethics statement}

The animal experiments in this study were conducted under the institutional guidelines of the Guangdong Province and approved by the Use Committee for Animal Care and the Sun Yat-sen University Institute Research Ethics Committee.

\section{Cells and virus}

The HepG2 and Hep3B HCC cell lines (obtained from Dr. Qi Zhang, Laboratory of Hepatic Disease of the Third Affiliated Hospital of Sun Yat-sen University, Guangzhou, China) and Vero cells (African green monkey kidney, purchased from The Committee on Type Culture Collection of Chinese Academy of Sciences, Shanghai, China) were cultured at $37^{\circ} \mathrm{C}$ and $5 \% \mathrm{CO}_{2}$ in DMEM with glucose (4.5 g/l, Mediatech, Inc., Herndon, VA) that was supplemented with $10 \%$ fetal calf serum (Hyclone Laboratories, Logan, UT). The SMMC-7721, BEL-7404, and BEL-7405 HCC and the HL-7702 human hepatic immortalized cell lines (obtained from Dr. Qi Zhang, Laboratory of hepatic disease of the Third Affiliated Hospital of Sun Yat-sen University, Guangzhou, China) were cultured at $37^{\circ} \mathrm{C}$ and $5 \% \mathrm{CO}_{2}$ in RPMI1640 with glucose (4.5 g/l, Mediatech, Inc., Herndon, VA) that was supplemented with $10 \%$ fetal calf serum (Hyclone Laboratories, Logan, UT).

The G47 $\Delta$ oncolytic herpes simplex virus was provided by MediGene, Inc. (San Diego, CA), and propagated in Vero cells cultured in DMEM containing 3\% IFCS (inactivated fetal calf serum) at $34.5^{\circ} \mathrm{C}$, as has been 
previously described. Briefly, the G47 $\Delta$ viruses were diluted in PBS/1\% IFCS. Vero cells were infected with a MOI of $0.02-0.03$ and incubated in a $37^{\circ} \mathrm{C}\left(5 \% \mathrm{CO}_{2}\right)$ incubator. After 90 minutes, the viral inoculum was removed, DMEM $/ 3 \%$ IFCS was added, and cells were incubated at $34.5^{\circ} \mathrm{C}\left(5 \% \mathrm{CO}_{2}\right)$ for approximately 2-3 days until total CPE occurred (the cells were rounded and refractive). Finally, the infected cells were harvested and resuspended in a 1:1 mix of DMEM (no serum) and the virus buffer [150 mM NaCl/20 mM Tris ( $\mathrm{pH} 7.5)]$. The cell suspension was rapidly frozen on $\mathrm{EtOH} /$ dry ice, and viral release was achieved by repeating the freeze-thaw process 3 times to lyse the cells. The cell debris was removed by lowspeed centrifugation $\left(2000 \mathrm{~g}\right.$ for $10 \mathrm{~min}$ at $4^{\circ} \mathrm{C}$ ). A plaque assay on the resultant $\mathrm{G} 47 \Delta$ progeny was performed on Vero cells at $37^{\circ} \mathrm{C}$ to determine the viral titer.

\section{In vitro cytotoxicity}

For cytotoxicity assay, cells were seeded in 6-well plates at $1 \times 10^{5}$ cells per well. The cells were infected with G47 $\Delta$ at a MOI of 0.01 and 0.1 when the cells were $50 \%$ confluent, while the controls were mock infected with PBS. After 24-hour incubation at $37^{\circ} \mathrm{C}$, the number of surviving cells was counted everyday with a hemocytometer; the cells were washed twice with $1 \mathrm{ml}$ of phosphatebuffered saline (PBS) to eliminate floating cells prior to counting. X-gal staining was performed daily, as described below, to show the infected cells.

\section{X-gal histochemistry}

On days 1-5 post-infection, the culture medium was removed, and the cells were fixed with $0.2 \%$ glutaraldehyde $/ 2 \%$ paraformaldehyde for $5 \mathrm{~min}$. The cells were then washed 3 times with PBS and incubated with X-gal substrate solution [PBS (pH 7.2), containing $0.5 \mathrm{mg} / \mathrm{ml}$ 5-bromo-4-chloro-3indolyl- $\beta$-D-galactopyranoside, $5 \mathrm{mmol} / \mathrm{L}$ potassium ferricyanide, $5 \mathrm{mmol} / \mathrm{L}$ potassium ferrocyanide, $2 \mathrm{mmol} / \mathrm{L}$ magnesium chloride] at $37^{\circ} \mathrm{C}$ for 2 hours.

\section{Animal studies}

Four-week-old male Balb/c nude mice were purchased from the Shanghai Institutes for Biological Sciences,

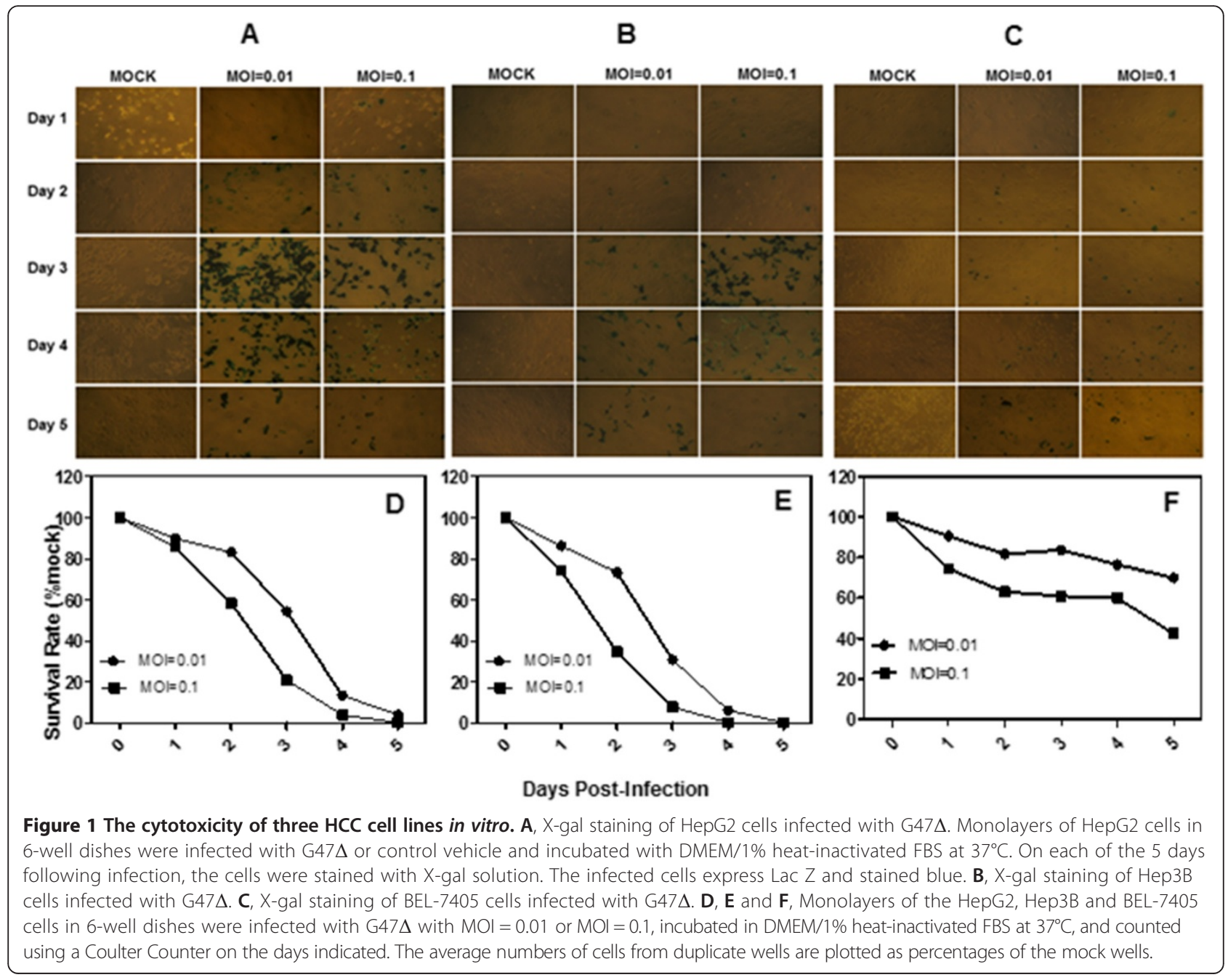


CAS, Shanghai, China and bred with five mice in each cage. Each mouse was anesthetized with an i.p. injection of 0.60 to $0.80 \mathrm{ml} \mathrm{10 \%} \mathrm{Chloral} \mathrm{Hydrate.} \mathrm{All} \mathrm{the}$ animal procedures were approved by the Sun Yat-sen University Institute Research Ethics Committee and the Use Committee for Animal Care. The mice were monitored daily for palpable (approximate 5-mm maximal diameter) tumor formation, and the tumors were measured using a Vernier caliper (the length was designated as "a", and the width was designated as "b"). The animals were weighed twice weekly.

\section{Subcutaneous tumor treatment}

The HCC SMMC-7721 $\left(2 \times 10^{6}\right)$ and BEL-7404 $\left(3 \times 10^{6}\right)$ cells were suspended in $100 \mu \mathrm{l}$ of RPMI 1640 complete culture with 25\% Matrigel (BD Biosciences) and implanted subcutaneously (s.c.) into the left flanks of 4-week-old nude mice. When the s.c. tumors were palpable, the s.c. tumors were inoculated twice weekly for two weeks with $2 \times 10^{7} / 50$ ul of G47 $\Delta$ or with the virus buffer [150 mM $\mathrm{NaCl}, 20 \mathrm{mM}$ Tris, (pH 7.5)] as a control. The tumor size was measured by Vernier calipers, and the tumor volume was calculated $\left(\mathrm{V}=\mathrm{a} \times \mathrm{b}^{2} / 2\right)$. If the animals appeared moribund (lethargy, a hunched or recumbent posture, a rough coat or limited ambulatory movements in response to stimulation) or the maximal diameter of their tumors exceeded $18 \mathrm{~mm}$, they were sacrificed and the date of death was recorded for the survival studies. The s.c. tumors were excised and then fixed in formaldehyde and embedded in paraffin for histological staining (hematoxylin-eosin).

\section{Virus biodistribution studies}

The SMMC-7721 and BEL-7404 s.c. carcinoma-bearing $\mathrm{Balb} / \mathrm{c}$ mice were treated 4 times with $2 \times 10^{7} \mathrm{pfu} / 50 \mathrm{ul}$ of $\mathrm{G} 47 \Delta$, as described above. The s.c. tumors were removed and embedded with tissue freezing medium

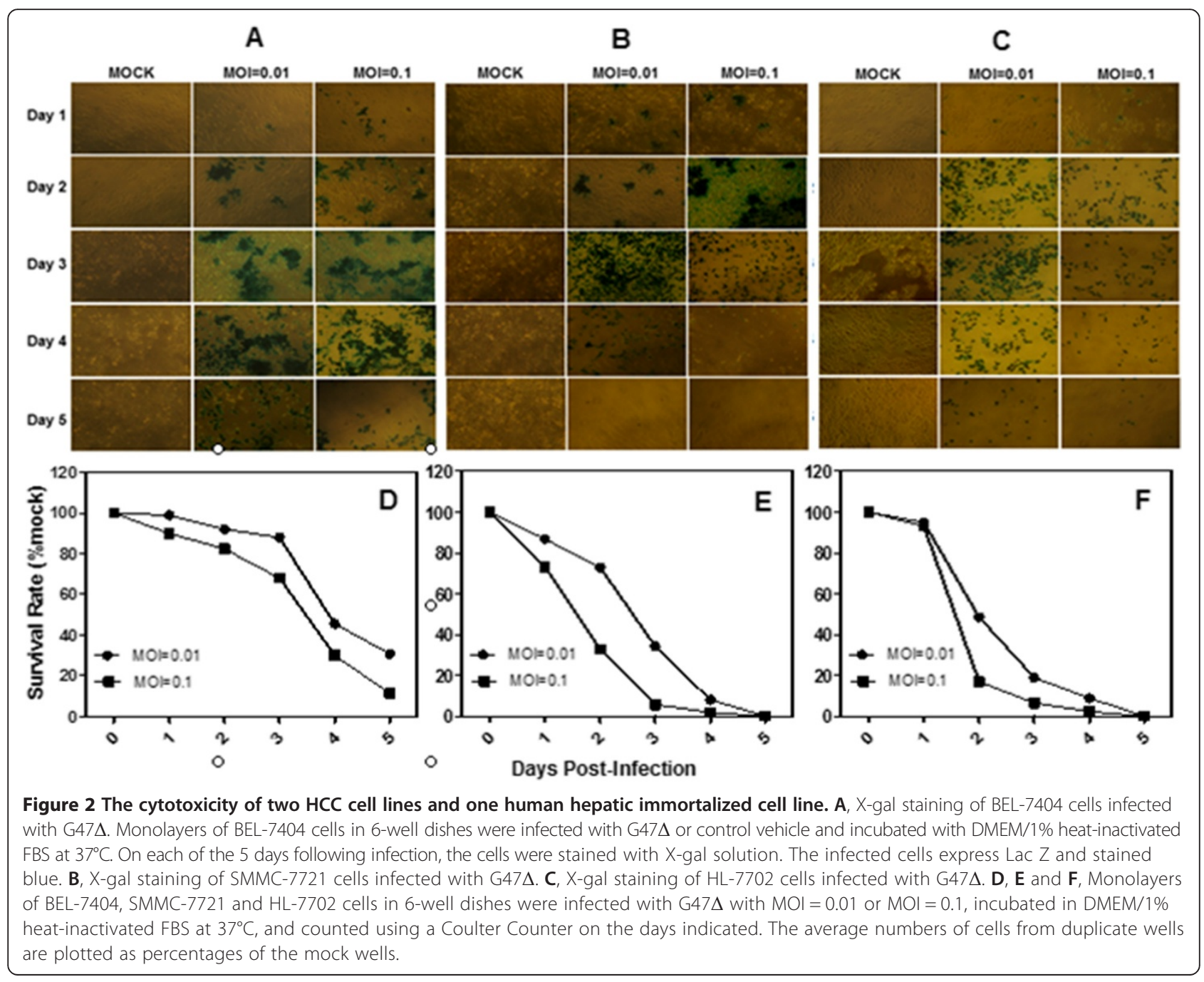


and immediately frozen in dry ice. Cryostat sections (10 $\mu \mathrm{m}$-thick) were prepared for biochemical staining of the LacZ enzyme. The sections were fixed with $2 \%$ paraformaldehyde in PBS for 10 minutes and washed with PBS 3 times for $15 \mathrm{~min}$. Next, slides were incubated with PBS containing $2 \mathrm{mmol} / \mathrm{L}$ magnesium chloride, $0.01 \%$ sodium deoxycholate, and $0.02 \%$ NP40 for 10 minutes at $4^{\circ} \mathrm{C}$. The sections were stained with a substrate solution [PBS (pH 7.2), containing $1 \mathrm{mg} / \mathrm{mL}$ 5-bromo-4-chloro-3indolyl-h-D-galactopyranoside, $5 \mathrm{mmol} / \mathrm{L}$ potassium ferricyanide, $5 \mathrm{mmol} / \mathrm{L}$ potassium ferrocyanide, $2 \mathrm{mmol} / \mathrm{L}$ magnesium chloride, $0.01 \%$ sodium deoxycholate, and $0.02 \% \mathrm{NP} 40]$ at $34^{\circ} \mathrm{C}$ for 4 hours or over-night. The sections were washed with $\mathrm{PBS} / 2 \mathrm{mmol} / \mathrm{L}$ EDTA and counterstained with eosin before mounting.

\section{Results}

\section{In vitro cytotoxicity}

To assess the susceptibility of human HCC cells and a hepatic immortalized cell line to oncolytic HSV G47A cytotoxicity, monolayers of the HepG2, Hep3B, SMMC7721, BEL-7404, and BEL-7405 human HCC cells and the HL-7702 human hepatic immortalized cell line were infected with $\mathrm{G} 47 \Delta$ at low MOI's (MOI $=0.01$, MOI $=0.1$ ). By day 5 , more than $95 \%$ and $100 \%$ of the HepG2, Hep3B and SMMC-7721 HCC cells had been killed after infection with MOI's of 0.01 and 0.1, respectively (Figure 1D, E and Figure 2E), similar to the HL-7702 human hepatic immortalized cells (Figure 2F).
A slight decrease in effect was observed in the BEL-7404 hepatocarcinoma cells; more than $70 \%$ and $90 \%$ of the cells had been killed by day 5 after infection with MOI's of 0.01 and 0.1, respectively (Figure 2D), while the BEL-7405 hepatocarcinoma cells were less sensitive, $29.9 \%$ and $57.7 \%$ of the cells killed by day 5 after infection with MOI's of 0.01 and 0.1 , respectively (Figure 1F). The infected cells were stained by X-gal histochemistry (G47 $\Delta$ contain the lacZ transgene in the ICP6 region). The infected cells and the spread of the G47 $\Delta$ viruses are shown by the blue staining in Figure 1A, B and Figure 2A, B.

\section{Efficacy of G47 $\Delta$ on s.c. hepatocarcinoma tumors}

The SMMC-7721 and BEL-7404 cells were used for s.c. implantation in vivo.. S.c. tumors were established in the left flank of male Balb/c nude mice, followed by intratumoral injection with G47 $\Delta$ when the tumors were palpable. To evaluate virus replication in vivo, the G47 $\Delta$-treated mice were sacrificed, and X-gal histochemistry was performed on the sectioned s.c. tumors. The blue-stained areas represent G47 $\Delta$ replication (Figure 3B, D).

Similar to the in vitro results, inoculation with G47 $\Delta$ $\left(2 \times 10^{7} \mathrm{pfu}\right.$, four times) elicited a prominent antitumor effect and significantly inhibited tumor growth. Following G47 $\Delta$ treatment, complete regression was observed in 5 of 6 mice bearing s.c. SMMC-7721 tumors and in 4 of 6 mice bearing BEL-7404 tumors (Figure 4C, G). The animals were sacrificed on day 82 (for SMMC-7721) or day 75 (for BEL-7404), by which time the tumors

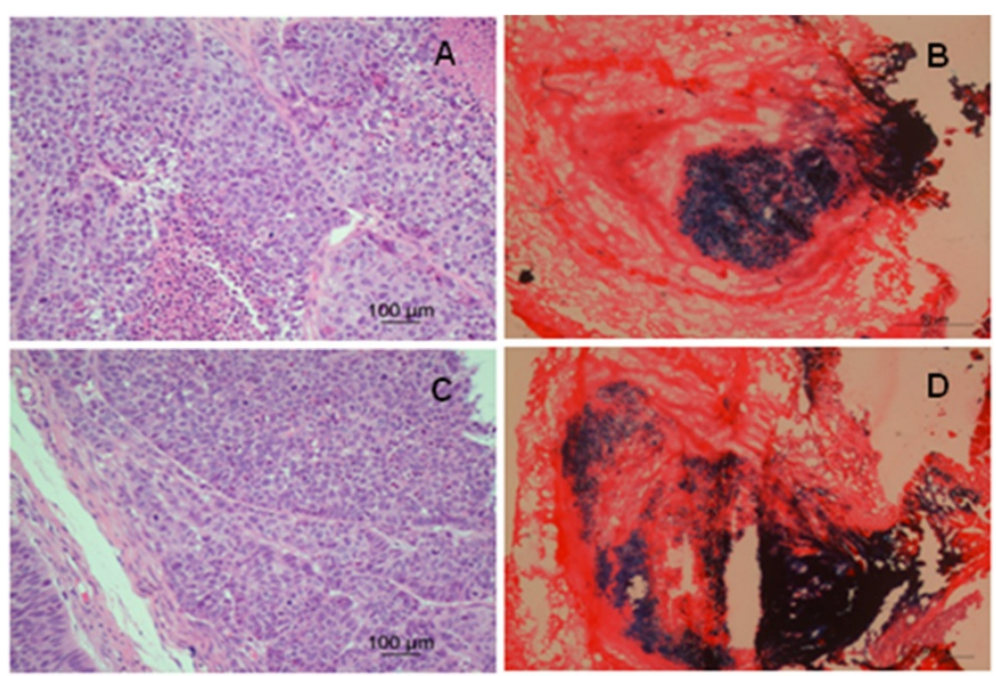

Figure 3 Established s.c. tumors from HCC SMMC-7721 and BEL-7404 cells. The cells were suspended in $100 \mu$ l of RPMI 1640 complete culture with 25\% Matrigel (BD Biosciences) and subcutaneously implanted into the left flanks of 4-week-old nude mice. When the s.c. tumors were palpable, mice were inoculated into the s.c. tumor twice a week with $2 \times 10^{7} / 50 \mathrm{ul}$ of G47 $\Delta$ or virus buffer [150 mM NaCl, $20 \mathrm{mM}$ Tris, (pH 7.5)] for control. H-E staining of SMMC-7721 (A) and BEL-7404 (C) s.c. tumors ( $\times 200)$. Coronal sections through SMMC-7721 (B) and BEL-7404 (D) s.c. tumors 3 days after $\mathrm{G} 47 \Delta$ ( $2 \times 10^{7} \mathrm{pfu}$ ) injection to illustrate the virus replication in the s.c. tumors. Sections were stained with X-gal, and counterstained with eosin to identify cells containing replicating G47 (blue). 

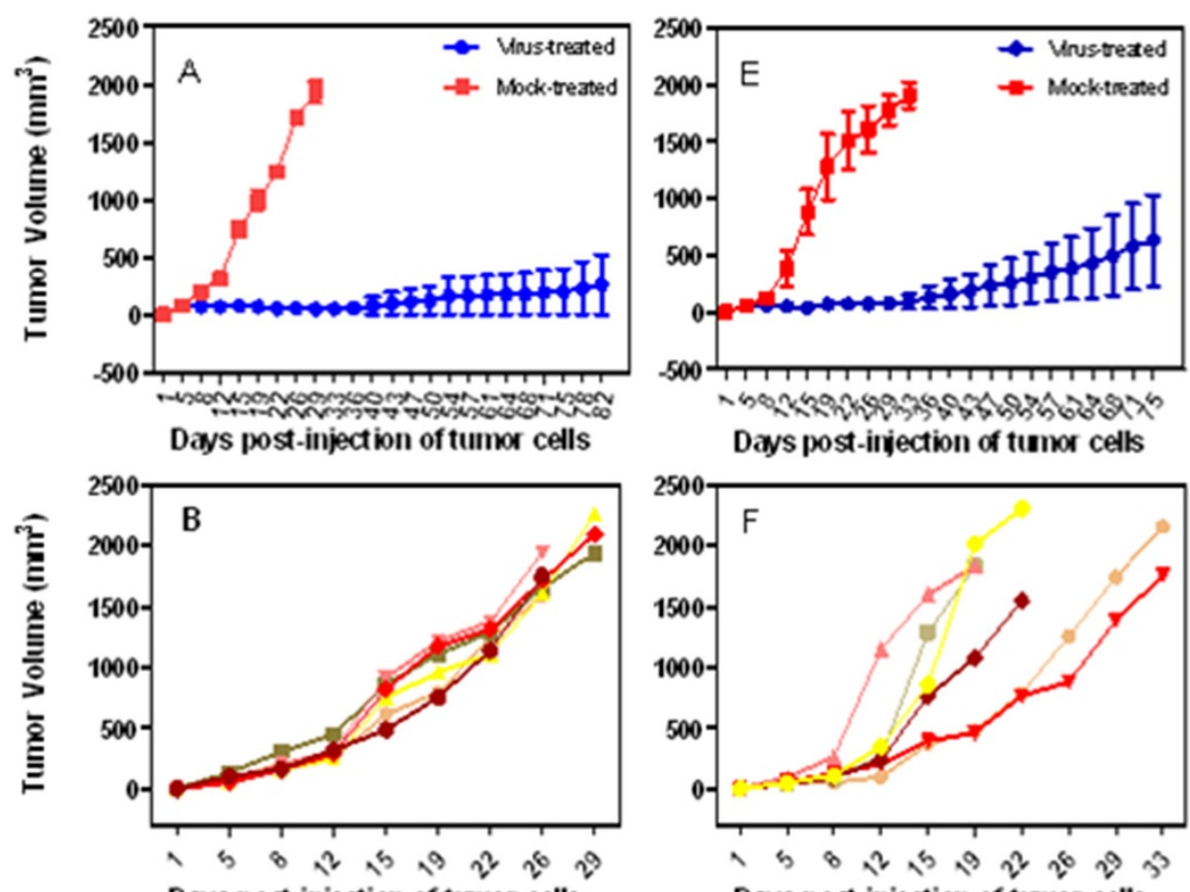

Days post-injection of tumbr cells

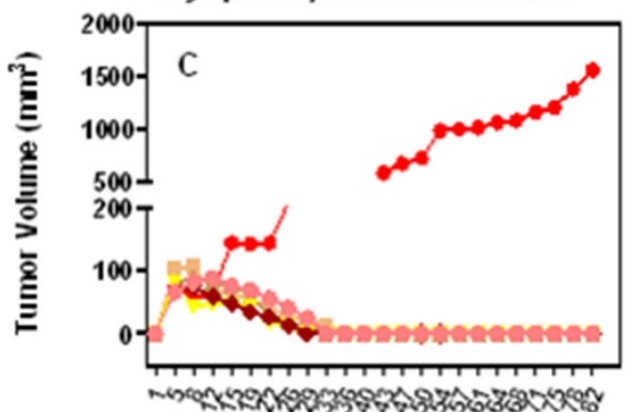

Days post-injection of tumbr cels
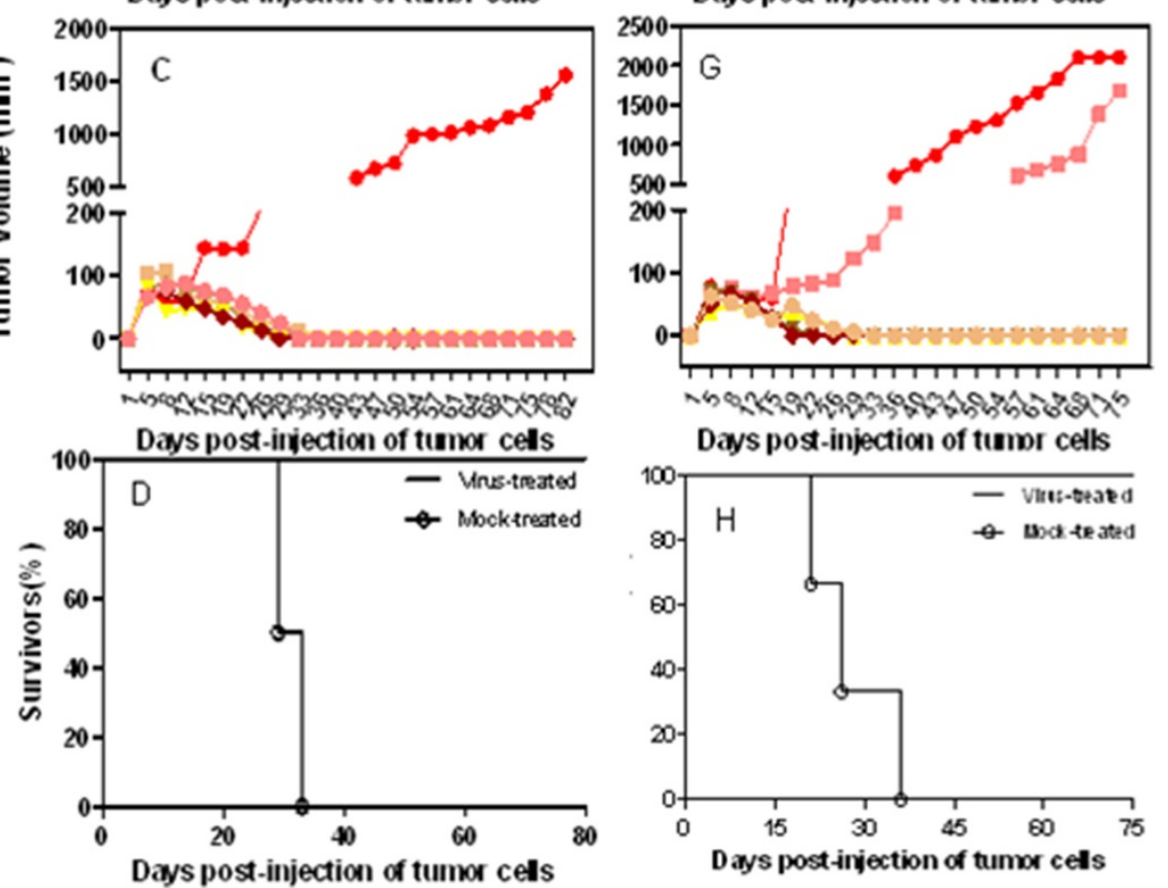

Days post-injection of tumbr cells

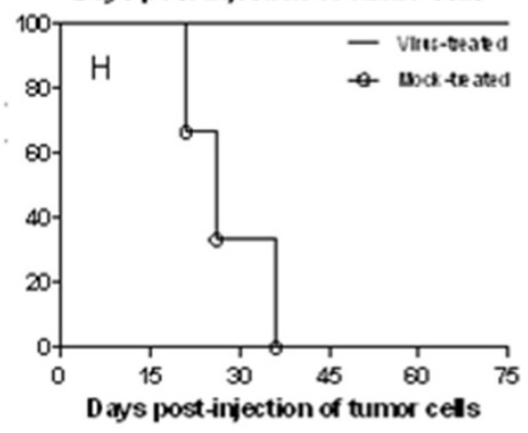

Figure 4 Treatment of s.c. SMMC-7721 and BEL-7404 tumors with G47 $\triangle$. The tumor size was measured by Vernier calipers, and the tumor volume was calculated $\left(V=a \times b^{2} / 2\right)$. The animals were sacrificed if they seemed moribund or the maximal diameter of their tumors exceeded $18 \mathrm{~mm}$, and that day was recorded as the date of death for the survival analysis. G47 $\Delta$ significantly delayed tumor progression compared with mock treatment. The tumors of 5 SMMC-7721 and 4 BEL-7404 mice in the treated groups regressed completely. A, The mean tumor volumes in the virus-treated and mock-treated SMMC-7721 groups at different times. $\mathbf{B}$ and $\mathbf{C}$, The growth of individual tumors in the mock and virus treated SMMC-7721 groups. D, The median survival time for the mice with s.c. SMMC-7721 tumors was increased from 27.5 days for the mock-treated animals to over 82 days for the G47D-treated animals. E, The mean tumor volumes in the virus-treated and mock-treated BEL-7404 groups at different times. $\mathbf{F}$ and $\mathbf{G}$. The growth of individual tumors in the mock and virus treated BEL-7404 groups. $\mathbf{H}$, The median survival time for the mice with s.c. BEL-7404 tumors was increased from 21 days for the mock-treated animals to over 75 days for the G47 $\Delta$-treated animals. 
in the specific group had grown to approximately $18 \mathrm{~mm}$ in maximal diameter. The G47 $\Delta$ treatment significantly extended the survival of the mice bearing the s.c. SMMC-7721 and BEL-7404 tumors, with median survival times of 82 and 75 days, respectively, compared to median survival times of 27.5 and 21 days, respectively, in the mock treated groups $(\mathrm{P}<0.05$, log-rank test) (Figure 4D, H).

\section{Discussion}

We evaluated the cytopathic effects of third-generation oncolytic HSV G47 $\Delta$ on human HCC and immortalized hepatic cells. Additionally, we demonstrated the therapeutic value of HSV G47 $\Delta$ in the treatment of HCC in vivo.

G47 $\Delta$ has three deletions/mutations, $\gamma 34.5$, UL39 and $\alpha 47$, that restrict replication to tumor cells. $\gamma 34.5$ is required for HSV to replicate in the brain or cause encephalitis [31-33]. The protein product of $\gamma 34.5$ precludes the halting of host protein synthesis in infected cells by dephosphorylating eIF2 $\alpha$ [34]. $\gamma 34.5^{-}$mutants lose neurovirulence, and their replication is attenuated in normal cells. However, the replication of $\gamma 34.5^{-}$mutants is unaffected in dividing tumor cells. The virus is further mutated by a lacZ gene insertion into the gene encoding ICP6, which is required for efficient viral growth in nondividing cells but not in many dividing cells in tissue cultures [35]. ICP6 is the large subunit of the viral ribonucleotide reductase, which is a key enzyme required synthesizing deoxyribonucleic acid in nondividing cells $[35,36]$. Without this enzyme, DNA replication is blocked in normal cells. Mammalian ribonucleotide reductase is elevated in tumor cells relative to normal cells; thus, the insertional inactivation of the gene encoding ICP6 guarantees the preferential replication of G47 $\Delta$ in tumor cells [36]. Additionally, the mutation in the ICP6 gene makes the virus more sensitive to acyclovir and ganciclovir [37], which can augment its safety for clinical use. In addition to its direct cytotoxic effects, G47 $\Delta$ is also capable of inducing antitumor immune responses [38-40]. The $\alpha 47$ gene binds to the transporter associated with antigen presentation (TAP) and blocks peptide loading of MHC class I molecules [41]. There is a $\alpha 47$ deletion in G47 $\Delta$ [31]. This deletion increases MHC class I presentation, stimulates lymphocytes, and decreases NK cytolysis of infected cells, which can broaden the activation of an antitumor immune response [30]. This ability is an important feature for treating metastatic tumors, particularly in patients with severely limited treatment options. The $\alpha 47$ mutation also places the late US11 gene under the control of the immediateearly $\alpha 47$ promoter. This shift in control blocks the halting of host protein synthesis and results in amplified growth of $\gamma 34.5^{-}$mutants and a boost in the cytotoxicity in tumor cells [34]. These multiple mutations make pathogenic reversion due to recombination nearly impossible and guarantee an important inherent safety mechanism for G47 $\Delta$ treatment. The combination of safety and efficacy led us to explore G47 $\Delta$ as a therapeutic agent for malignant tumors. Recently, G47 $\Delta$ has entered phase 1 clinical trial for progressive glioblastoma.

Our results demonstrate that G47 $\Delta$ can effectively kill different human HCC cell lines. Cytotoxic effects were observed in the HepG2, Hep3B, SMMC-7721, BEL-7404 and BEL-7405 cell lines. The efficiency of G47 $\Delta$ in killing malignant HCC cells and inhibiting the growth of xenograft tumors, offers a promising therapeutic strategy in treating human hepatic tumors. As typical surgical resection may be not always possible or would induce serious complications, this new therapeutic treatment strategy for hepatic cancer should be of benefit to patients with hepatic cancer, especially those with late-stage cancer that have lost the opportunity of surgery. We also demonstrated the cytopathic effects of G47 $\Delta$ on the HL-7702 human hepatic immortalized cell line at a very low MOI. Interestingly, immortalization of Schwann cells enhances their permissiveness to oncolytic HSV G207 [42]. Bypass of senescence and immortalization are considered to be early steps in tumor development, and thus G47 $\Delta$ may be active at an early stage of tumorigenesis. So far, G47 $\Delta$ has not posed a safety concern; thus, it could be used not only as a therapeutic strategy but also a preventive agent in premalignant diseases, such as hepatitis and cirrhosis.

To investigate the in vivo HCC antitumor effects of G47D, we established s.c. xenograft models of HCC using 2 different cell lines: SMMC-7721 and BEL-7404. G47 $\Delta$ was administered to the Balb/c nude mice twice a week for 2 weeks without any observable toxicity. A higher survival rate and significant reduction in tumor growth relative to the mock-treated groups were observed after G47 $\Delta$ therapy. Many of s.c. tumors from both the SMMC-7721 and BEL-7404 groups of G47Dtreated $\mathrm{Balb} / \mathrm{c}$ nude mice gradually regressed, suggesting that G47 $\Delta$ has the potential to effectively inhibit different types of HCC tumors in clinical applications.

In conclusion, the third-generation oncolytic HSV G47 $\Delta$ was effective as a tumoricidal agent in both HCC and immortalized hepatic cells. This feature suggests its use as both a therapeutic and preventive agent for human HCC. Intratumoral injection of G47 $\Delta$ induced an obvious therapeutic effect on HCC, which may lead to future clinical applications in cancer therapy.

\section{Competing interests}

The authors declare that they have no competing interests.

\section{Authors' contributions}

RL designed this study, JW and LX carried out the study and drafted the manuscript, WZ and PH carried out the statistical analysis. MZ assisted with manuscript preparation and data analysis. SR assisted with technical advice and manuscript revision. All authors read and approved the final manuscript. 


\section{Acknowledgements}

Our work is supported by the National Natural Science Foundation of China (No. 81372815, 81172523).

\section{Author details}

Breast Cancer Center, The Third Affiliated Hospital of Sun Yat-sen University, 600 Tianhe Road, 510630 Guangzhou, China. ²Department of Oncology and Hematology, The First Affiliated Hospital of Guangzhou Medical University, Guangzhou, China. ${ }^{3}$ Department of Colorectal Surgery, Cancer Hospital, Chinese Academy of Medical Sciences, Peking Union Medical College, 17 Panjiayuan Nanli, Chaoyang District, 100021 Beijing, China. ${ }^{4}$ State Key Laboratory of Oncology in South China, Sun Yat-Sen University Cancer Centre, Guangzhou, China. ${ }^{5}$ Department of Neurosurgery, Massachusetts General Hospital and Harvard Medical School, Boston, USA

Received: 23 October 2013 Accepted: 5 August 2014

Published online: 19 September 2014

\section{References}

1. Jain S, Singhal S, Lee $P, X u$ R: Molecular genetics of hepatocellular neoplasia. Am J Transl Res 2010, 2(1):105-118.

2. Parkin DM, Bray F, Ferlay J, Pisani P: Global cancer statistics, 2002. CA Cancer J Clin 2005, 55(2):74-108.

3. Paul SB, Manjunatha YC, Acharya SK: Palliative treatment in advanced hepatocellular carcinoma: has it made any difference? Trop Gastroenterol 2009, 30(3):125-134.

4. Padma S, Martinie JB, lannitti DA: Liver tumor ablation: percutaneous and open approaches. J Surg Oncol 2009, 100(8):619-634.

5. Montalto G, Cervello M, Giannitrapani L, Dantona F, Terranova A Castagnetta LA: Epidemiology, risk factors, and natural history of hepatocellular carcinoma. Ann N Y Acad Sci 2002, 963:13-20.

6. Block TM, Mehta AS, Fimmel CJ, Jordan R: Molecular viral oncology of hepatocellular carcinoma. Oncogene 2003, 22(33):5093-5107.

7. Marrero JA: Hepatocellular carcinoma. Curr Opin Gastroenterol 2006, 22(3):248-253.

8. Oyagbemi AA, Azeez OI, Saba AB: Hepatocellular carcinoma and the underlying mechanisms. Afr Health Sci 2010, 10(1):93-98.

9. Arzumanyan A, Reis HM, Feitelson MA: Pathogenic mechanisms in HBV- and HCV-associated hepatocellular carcinoma. Nat Rev Cancer 2013, 13(2):123-135.

10. Nebbia G, Peppa D, Maini MK: Hepatitis B infection: current concepts and future challenges. QJM 2012, 105(2):109-113.

11. Sarbah SA, Gramlich T, Younoszai A, Osmack P, Goormastic M, Grosso L, Cooper JN, Di Bisceglie A, Seneca R, Younossi ZM: Risk factors for hepatocellular carcinoma in patients with cirrhosis. Dig Dis Sci 2004, 49(5):850-853.

12. Barraud $\mathrm{H}$, Bronowicki JP: [Curative treatment of hepatocellular carcinoma]. Rev Prat 2013, 63(2):229-233.

13. Llovet JM: Updated treatment approach to hepatocellular carcinoma J Gastroenterol 2005, 40(3):225-235.

14. Simillis C, Constantinides VA, Tekkis PP, Darzi A, Lovegrove R, Jiao L, Antoniou A: Laparoscopic versus open hepatic resections for benign and malignant neoplasms-a meta-analysis. Surgery 2007, 141(2):203-211.

15. Schemmer P, Friess H, Hinz U, Mehrabi A, Kraus TW, Z'Graggen K, Schmidt J, Uhl W, Buchler MW: Stapler hepatectomy is a safe dissection technique: analysis of 300 patients. World J Surg 2006, 30(3):419-430.

16. Bolondi L, Sofia S, Siringo S, Gaiani S, Casali A, Zironi G, Piscaglia F Gramantieri L, Zanetti M, Sherman M: Surveillance programme of cirrhotic patients for early diagnosis and treatment of hepatocellular carcinoma: a cost effectiveness analysis. Gut 2001, 48(2):251-259.

17. Wong J, Lee C, Zhang K, Rennie PS, Jia W: Targeted oncolytic herpes simplex viruses for aggressive cancer. Curr Pharm Biotechnol 2012, 13(9):1786-1794.

18. Martuza RL, Malick A, Markert JM, Ruffner KL, Coen DM: Experimental therapy of human glioma by means of a genetically engineered virus mutant. Science 1991, 252(5007):854-856.

19. Varghese S, Rabkin SD: Oncolytic herpes simplex virus vectors for cancer virotherapy. Cancer Gene Ther 2002, 9(12):967-978.

20. Bennett JJ, Delman KA, Burt BM, Mariotti A, Malhotra S, Zager J, Petrowsky H, Mastorides S, Federoff $\mathrm{H}$, Fong $\mathrm{Y}$ : Comparison of safety, delivery, and efficacy of two oncolytic herpes viruses (G207 and NV1020) for peritoneal cancer. Cancer Gene Ther 2002, 9(11):935-945.
21. McAuliffe PF, Jarnagin WR, Johnson P, Delman KA, Federoff $H$, Fong $Y$ : Effective treatment of pancreatic tumors with two multimutated herpes simplex oncolytic viruses. J Gastrointest Surg 2000, 4(6):580-588.

22. Delman KA, Bennett JJ, Zager JS, Burt BM, McAuliffe PF, Petrowsky H, Kooby DA, Hawkins WG, Horsburgh BC, Johnson P, Fong Y: Effects of preexisting immunity on the response to herpes simplex-based oncolytic viral therapy. Hum Gene Ther 2000, 11(18):2465-2472.

23. Cozzi PJ, Burke PB, Bhargav A, Heston WD, Huryk B, Scardino PT, Fong Y. Oncolytic viral gene therapy for prostate cancer using two attenuated, replication-competent, genetically engineered herpes simplex viruses. Prostate 2002, 53(2):95-100

24. Cozzi PJ, Malhotra S, McAuliffe P, Kooby DA, Federoff HJ, Huryk B, Johnson P, Scardino PT, Heston WD, Fong Y: Intravesical oncolytic viral therapy using attenuated, replication-competent herpes simplex viruses G207 and Nv1020 is effective in the treatment of bladder cancer in an orthotopic syngeneic model. FASEB J 2001, 15(7):1306-1308.

25. Shen $Y$, Nemunaitis J: Herpes simplex virus 1 (HSV-1) for cancer treatment. Cancer Gene Ther 2006, 13(11):975-992.

26. Liu S, Dai M, You L, Zhao Y: Advance in herpes simplex viruses for cance therapy. Sci China Life Sci 2013, 56(4):298-305.

27. Markert JM, Medlock MD, Rabkin SD, Gillespie GY, Todo T, Hunter WD Palmer CA, Feigenbaum F, Tornatore C, Tufaro F, Martuza RL: Conditionally replicating herpes simplex virus mutant, G207 for the treatment of malignant glioma: results of a phase I trial. Gene Ther 2000, 7(10):867-874

28. Poortmans PM, Ataman F, Davis JB, Bartelink H, Horiot JC, Pierart M, Collette L, Van Tienhoven G: Quality assurance in the EORTC phase III randomised 'boost vs. no boost' trial for breast conserving therapy: comparison of the results of two individual case reviews performed early and late during the accrual period. Adiother Oncol 2005, 76(3):278-284.

29. Russell SJ, Peng KW, Bell JC: Oncolytic virotherapy. Nat Biotechnol 2012, 30(7):658-670.

30. Todo T, Martuza RL, Rabkin SD, Johnson PA: Oncolytic herpes simplex virus vector with enhanced $\mathrm{MHC}$ class I presentation and tumor cell killing. Proc Natl Acad Sci U S A 2001, 98(11):6396-6401.

31. Chou J, Kern ER, Whitley RJ, Roizman B: Mapping of herpes simplex virus-1 neurovirulence to gamma 134.5, a gene nonessential for growth in culture. Science 1990, 250(4985):1262-1266.

32. Markert JM, Malick A, Coen DM, Martuza RL: Reduction and elimination of encephalitis in an experimental glioma therapy model with attenuated herpes simplex mutants that retain susceptibility to acyclovir. Neurosurgery 1993, 32(4):597-603.

33. Chambers R, Gillespie GY, Soroceanu L, Andreansky S, Chatterjee S, Chou J, Roizman B, Whitley RJ: Comparison of genetically engineered herpes simplex viruses for the treatment of brain tumors in a scid mouse model of human malignant glioma. Proc Natl Acad Sci U S A 1995, 92(5):1411-1415.

34. Mohr I, Gluzman Y: A herpesvirus genetic element which affects translation in the absence of the viral GADD34 function. EMBO J 1996, 15(17):4759-4766.

35. Goldstein DJ, Weller SK: Herpes simplex virus type 1-induced ribonucleotide reductase activity is dispensable for virus growth and DNA synthesis: isolation and characterization of an ICP6 lacZ insertion mutant. J Virol 1988, 62(1):196-205.

36. Carroll NM, Chiocca EA, Takahashi K, Tanabe KK: Enhancement of gene therapy specificity for diffuse colon carcinoma liver metastases with recombinant herpes simplex virus. Ann Surg 1996, 224(3):323-329. discussion 329-330.

37. Mineta T, Rabkin SD, Martuza RL: Treatment of malignant gliomas using ganciclovir-hypersensitive, ribonucleotide reductase-deficient herpes simplex viral mutant. Cancer Res 1994, 54(15):3963-3966.

38. Toda M, Rabkin SD, Kojima H, Martuza RL: Herpes simplex virus as an in situ cancer vaccine for the induction of specific anti-tumor immunity. Hum Gene Ther 1999, 10(3):385-393.

39. Thomas DL, Fraser NW: HSV-1 therapy of primary tumors reduces the number of metastases in an immune-competent model of metastatic breast cancer. Mol Ther 2003, 8(4):543-551.

40. Liu BL, Robinson M, Han ZQ, Branston RH, English C, Reay P, McGrath Y, Thomas SK, Thornton M, Bullock P, Love CA, Coffin RS: ICP34.5 deleted herpes simplex virus with enhanced oncolytic, immune stimulating, and anti-tumour properties. Gene Ther 2003, 10(4):292-303. 
41. York IA, Roop C, Andrews DW, Riddell SR, Graham FL, Johnson DC: A cytosolic herpes simplex virus protein inhibits antigen presentation to CD8+ T lymphocytes. Cell 1994, 77(4):525-535.

42. Farassati F, Pan W, Yamoutpour F, Henke S, Piedra M, Frahm S, Al-Tawil S, Mangrum WI, Parada LF, Rabkin SD, Martuza RL, Kurtz A: Ras signaling influences permissiveness of malignant peripheral nerve sheath tumor cells to oncolytic herpes. Am J Pathol 2008, 173(6):1861-1872.

doi:10.1186/s12935-014-0083-y

Cite this article as: Wang et al:: Treatment of human hepatocellular

carcinoma by the oncolytic herpes simplex virus G47delta. Cancer Cell International 2014 14:83.

\section{Submit your next manuscript to BioMed Central and take full advantage of:}

- Convenient online submission

- Thorough peer review

- No space constraints or color figure charges

- Immediate publication on acceptance

- Inclusion in PubMed, CAS, Scopus and Google Scholar

- Research which is freely available for redistribution 